\title{
„Badania publiczności muzeów w Polsce”. Projekt Narodowego Instytutu Muzealnictwa i 0chrony Zbiorów
}

\begin{abstract}
„Audience Research in Polish Museums”. Project Narodowego Instytutu Muzealnictwa i Ochrony Zbiorów
\end{abstract}

Project „Audience research in Polish museums” was started in March 2017 as a multi-annual project of the research and educational shape. The starting point was our belief that recognition of your own audience is the first step for each museum to frame the methods of performing your mission, creating educational programmes and offer for visitors. Regularly repeated, it helps museums to follow changes in the structure of the audience and in its intents, and to find common ground to form and maintain the cooperation with the public. Hitherto, NIMOZ completed two annual editions of the project: the pilot one in 2017 committed to the general overview of the Polish museums' audience and the second one in 2018 entitled „Museum in the local society”. The project is now being continued in the contexts of the elderly people as recipients of the museums' offer. To achieve the educational aims of the project we facilitate our studies to the museums, organize trainings for the museums' staff and publish the handbooks.

Keywords: audience research, museums, visitors, audience

Słowa kluczowe: badania publiczności, muzea, zwiedzający, publiczność 
Projekt „Badania publiczności muzeów w Polsce” jest projektem edukacyjno-badawczym, czy też raczej - by być precyzyjnym - badawczo-edukacyjnym, ponieważ punktem wyjścia do jego prowadzenia były i są na każdym z kolejnych etapów badania. Zaczynając od przeglądu literatury i dotychczasowych raportów, przez badania ankietowe, wywiady indywidualne i grupowe, badania zarówno ilościowe, jak i jakościowe. Jednak równie istotne jak poznanie publiczności jest przekonanie muzeów i muzealników, że systematyczne prowadzenie takich badań jest nie tylko przejawem muzealnej i kulturowej mody, ale przynieść może instytucji i jej pracownikom realną pomoc w pracy. Badawczo-edukacyjny charakter projektu jest efektem profilu instytucji, w ramach której został w 2017 roku zapoczątkowany i gdzie wciąż rozwija się, inspirowany innymi działaniami statutowymi.

Narodowy Instytut Muzealnictwa i Ochrony Zbiorów, o którym mowa, powstał w 2011 roku z przekształcenia innej instytucji - Ośrodka Ochrony Zbiorów Publicznych. Jest utworzoną przez Ministra Kultury i Dziedzictwa Narodowego instytucją kultury o charakterze eksperckim, koncentrującą się na obszarach muzealnictwa oraz ochronie zbiorów publicznych, wykonującą ponadto zadania z obszaru kompetencji administracji publicznej (np. udział w procedurze uzgadniania statutów muzeów samorządowych i regulaminów muzeów tzw. prywatnych, wypełnianie zadań instytucji zarządzającej powierzonymi Programami Ministra Kultury i Dziedzictwa Narodowego). NIMOZ wspomaga muzea w ich działalności, poprzez opracowywanie i prowadzenie szkoleń skierowanych do pracowników muzeów, publikacje, tworzenie i wydawanie opinii oraz prowadzenie projektów o charakterze edukacyjno-badawczym. Instytut stanowi zaplecze eksperckie i wsparcie zarówno dla Departamentu Dziedzictwa Kulturowego Ministerstwa Kultury i Dziedzictwa Narodowego, który bezpośrednio nadzoruje i Instytut, i muzea, jak i dla samych muzeów, ich dyrektorów, pracowników i organizatorów. Nierzadko odpowiadamy na pytania, na które sami wcześniej musimy poznać odpowiedź poprzez przeprowadzenie własnych badań i analizę wyników, a następnie opracowanie opinii.

Specyfiką projektu „Badania publiczności muzeów w Polsce” jest koncentracja na jednym tylko typie instytucji kultury, jednak instytucji wyspecjalizowanej w ochronie materialnego i niematerialnego dziedzictwa kultury. Powyższe założenie każe badaczom pamiętać, że publiczność jest w muzeum najważniejszą, choć równorzędną wobec zbiorów muzealnych wartością. Projekt dotyczy wszystkich muzeów i instytucji paramuzealnych w Polsce, przy całej ich różnorodności oraz ich zadań, takich jak wymieniane w art. 2 Ustawy o muzeach:

1) gromadzenie zabytków w statutowo określonym zakresie; 2) katalogowanie i naukowe opracowywanie zgromadzonych zbiorów; 3) przechowywanie gromadzonych zabytków, w warunkach zapewniających im właściwy stan zachowania i bezpieczeństwo, oraz magazynowanie ich w sposób dostępny do celów naukowych; 4) zabezpieczanie i konserwację zbiorów oraz, 
w miarę możliwości, zabezpieczanie zabytków archeologicznych nieruchomych oraz innych nieruchomych obiektów kultury materialnej i przyrody; 5) urządzanie wystaw stałych i czasowych; 6) organizowanie badań i ekspedycji naukowych, w tym archeologicznych; 7) prowadzenie działalności edukacyjnej; 7a) popieranie i prowadzenie działalności artystycznej i upowszechniającej kulturę; 8) udostępnianie zbiorów do celów edukacyjnych i naukowych; 9) zapewnianie właściwych warunków zwiedzania oraz korzystania ze zbiorów i zgromadzonych informacji; 10) prowadzenie działalności wydawniczej [Dz.U. 1997 nr 5 poz. 24 ze zm.].

W katalogu zadań muzeów wymienione są więc te, które służą publiczności, i przy których realizacji znajomość struktury zwiedzających, a czasem samych zwiedzających jako konkretnych ludzi, jest niezbędna - tak jak w działalności innego rodzaju instytucji kultury (np. teatrów, domów kultury czy bibliotek). Tym, co różni muzea od innych instytucji kultury w ich działaniach skierowanych do publiczności, jest to, że nie mogą one zapominać o swoich zbiorach - to one są podstawą tworzenia misji, strategii i programów krótko- i długoterminowych. I choć wiele muzeów, szczególnie w miejscowościach, gdzie nie ma domów kultury, musi je częściowo zastąpić w działalności społecznej, to jednak muzeum opiera się na zbiorach i tematach, dla którego zostało powołane, a swoje działania dla publiczności buduje wokół tych wyznaczników.

Na profil każdego projektu dotyczącego muzeów wpływa ich zróżnicowanie, zarówno pod względem wielkości (instytucji, liczby pracowników, ale i zbiorów), organizatora, struktury organizacyjnej, typu i rodzaju muzeum. Muzea w Polsce mogą mieć kilkanaście oddziałów i kilkuset pracowników (jak Muzeum Krakowa), mogą być muzeami bezoodziałowymi, ulokowanymi w dużej lub małej siedzibie, z kilkudziesięcioma pracownikami lub zatrudniające trzy osoby, a w przypadku muzeów tak zwanych prywatnych najczęściej jedną osobę - samego założyciela. Dla publiczności osoba organizatora muzeum nie ma bezpośredniego znaczenia, jednak na działalność muzeum ma czasem znaczny wpływ, co oddziałuje pośrednio na publiczność. Muzeum może być prowadzone przez organy państwa - ministerstwa (najczęściej, choć nie tylko Ministerstwo Kultury i Dziedzictwa Narodowego), samorządy (wyższego i niższego szczebla), może mieć status muzeum tak zwanego prywatnego [Grzonkowska 2019], którego założycielem może być osoba fizyczna, osoba prawna (np. fundacja), uczelnia, Kościół lub związek wyznaniowy, ale także firma czy instytucja. Część muzeów ma status współprowadzonych, co oznacza, iż ma dwóch lub więcej organizatorów, choć takie muzeum wpisane jest do rejestru instytucji kultury tylko jednego ze swych założycieli. Wykaz wszystkich muzeów w rozumieniu ustawy z dnia 21 listopada 1997 roku o muzeach [Dz.U. $1997 \mathrm{nr} 5$ poz. 24 ze zm.], czyli o statucie lub regulaminie uzgodnionym z ministrem właściwym do spraw kultury i ochrony dziedzictwa narodowego, prowadzony na stronie internetowej Ministerstwa Kultury i Dziedzictwa Narodowego, wymienia na dzień 30 maja 2019 roku 828 jednostek. Poza nimi istnieją 
też „muzea” niebędące muzeami w rozumieniu ustawy, których założyciele czy też właściciele nie uzgodnili statutu ani regulaminu z Ministrem Kultury i które są bardziej przedsiębiorstwami niż jednostkami nienastawionymi na zysk, co jest warunkiem koniecznym dla osiągnięcia statusu muzeum, jednak używające tej nazwy a często zbliżone działalnością do muzeów. Muzeami w rozumieniu ustawy o muzeach nie są także ogrody botaniczne ani zoologiczne, choć i one mają profil zbliżony do muzeów, i tak są traktowane na przykład przez Główny Urząd Statystyczny.

Podział muzeów w Polsce według ich organizatora pokazuje wykres 1. Zwraca uwagę to, że ponad połowę muzeów stanowią jednostki zakładane przez osoby prawne i fizyczne, a więc tak zwane muzea prywatne.

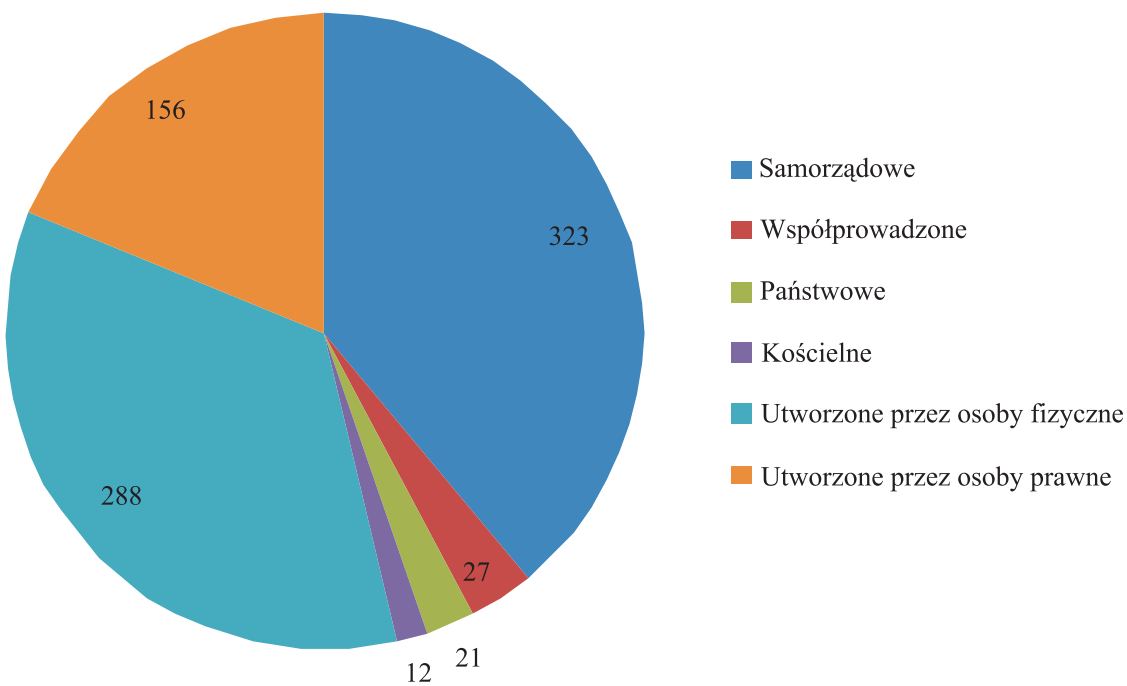

Wykres 1. Podział muzeów w Polsce według organizatora

Źródło: opracowanie własne na podstawie wykazu muzeów prowadzonego przez ministra właściwego do spraw kultury i ochrony dziedzictwa narodowego - stan na 29.05.2019 roku.

Na skomplikowany obraz instytucji, których publiczność mieliśmy badać, nakłada się jeszcze liczba muzeów w Polsce. Według wspomnianego wykazu muzeów, prowadzonego przez Ministra Kultury i Dziedzictwa Narodowego, ich liczba na dzień 30 maja 2019 roku wynosi 828, ale niemal z każdym dniem jest większa. Doliczając jednostki spoza wykazu, można powiedzieć, że zbliżamy się do 1000. Dane GUS podają większe liczby, ale wynika to między innymi z faktu, że wspomniany Urząd traktuje każdy oddział muzeum oddziałowego jako osobne muzeum. Biorąc jednak pod uwagę, że badamy publiczność muzeów, należało 
zastanowić się nad grupą docelową. Zgodnie z danymi GUS frekwencja w muzeach polskich w roku 2017 wyniosła 37,5 mln osób [GUS 2018a: 53], podczas gdy liczba ludności Polski w grudniu 2017 roku - niemal 38,5 mln [GUS 2018c: 13], co nie oznacza, oczywiście, że niemal każdy z mieszkańców Polski odwiedził w roku 2017 muzeum (należy wziąć po uwagę choćby szacowaną przez GUS na 18,3 mln osób liczbę turystów zagranicznych w Polsce w roku 2017 [GUS 2018b: 101]). Niemniej jednak w zestawieniu z pozostałymi odbiorcami kultury publiczność muzeów jest znaczącą grupą, co pokazują inne dane podane w raporcie GUS za rok 2017: na przykład dla teatrów i instytucji muzycznych - 13,3 mln [GUS 2018a: 57]. Grupa docelowa projektu jest więc szeroka, a dodatkowo należałoby podjąć decyzję, czy badamy tylko oglądających wystawy, czy także odwiedzających organizowane przez muzea wydarzenia, na przykład koncerty, spektakle, wykłady i niejednoznacznie klasyfikowaną Noc Muzeów.

Zaplanowane przez NIMOZ badania publiczności w założeniu powinny więc objąć wszystkie muzea w Polsce, wszystkich typów i rodzajów oraz całą populację Polski powyżej 3 roku życia. Planując badania, nie mogliśmy od razu myśleć o tak szerokim zakresie projektu. Docelowo dążyć będziemy do przeprowadzenia badań wszystkich muzeów w Polsce, jednak na etapie przygotowań do projektu i w efekcie pilotażu zdecydowaliśmy się na badania wycinkowe: ilościowe - obejmujące poprzez użycie ankiety internetowej większą liczbę muzeów, choć nie wszystkie; oraz jakościowe - dotyczące wybranej, choć reprezentatywnej grupy. Niniejsze założenie po dwóch latach projektu wydaje się słuszne.

Punktem wyjścia przy planowaniu projektu „Badanie publiczności muzeów w Polsce" było głębokie przekonanie zespołu, że pomimo wszystkich powyżej wymienionych komplikujących sytuację danych wyjściowych badania nie tylko są możliwe, ale wręcz konieczne dla rozwoju muzeów. Zdobyta w ten sposób wiedza pozwoli pracownikom instytucji dostosować program działalności, a może nawet misję, do obecnej publiczności. Publiczność muzeów nieustannie się zmienia, bo następują zmiany pokoleniowe, migracje ludności, a wydarzenia mogą wpływać na nastawienie publiczności w ciągu kilku zaledwie lat. Muzeum, mając wiedzę o zmianach swojej publiczności, może modyfikować program, strategię, a jeśli będzie to konieczne nawet misję. Jeśli badania publiczności wskażą na luki w przepływie informacji między muzeum a publicznością, co może świadczyć o problemach z komunikacją także wewnątrz samego muzeum: jeśli informacje o strukturze odbiorców wystaw nie są przekazywane kuratorom albo są przez nich ignorowane, świadczy to o konieczności zmian wewnętrznych. Prowadzone przez muzea badania publiczności pozwalają więc powiedzieć o muzeum więcej niż tylko o strukturze jego odbiorców i mogą zostać przez muzeum wykorzystane jako punkt wyjścia do ewentualnych działań zmierzających do doskonalenia instytucji.

Budując projekt, NIMOZ opierał się na doświadczeniu wcześniejszej lub obecnej pracy części członków zespołu w muzeach, doświadczeniu pracy z muzeami 
i dla muzeów zespołu i całego Instytutu, świadomości, że muzeum dbać musi nie tylko o swoją publiczność, ale również o zbiory, a także na obrazoburczym może przekonaniu, że nie wszystkie muzea mogą być „dla wszystkich”, bo każdy z nas jest inny i innych muzeów poszukuje. Muzea specjalistyczne, na przykład muzea techniki, medycyny czy literatury, mają swoich wiernych odwiedzających, choć nie każdy miłośnik malarstwa będzie zainteresowany muzeum sportu, a nie każdy pasjonat etnografii musi być jednocześnie oddany zwiedzaniu muzeów wojskowości. Muzea powinny być demokratyczne, nie powinny nikogo wykluczać, w praktyce jednak nie każde zbiory muzeów przyciągają szeroką publiczność, a wystawy tworzone „dla wszystkich” czasem nie znajdują zainteresowania prawie nikogo: ani pasjonatów tematu (jako zbyt uproszczone), ani laików (jako zbyt skomplikowane). Dobrze zrobiona wystawa, zbudowana na kilku poziomach przekazywanej wiedzy, jest oczywiście ideałem, do którego muzea wciąż dążą. W wypadku tak zaprojektowanej wystawy zgodzić się wypada, że „charakter zbiorów nie decyduje o popularności i nie jest czynnikiem warunkującym zainteresowanie odbiorców. Zasadnicze znaczenie ma sposób interpretacji zbiorów, stworzenie odpowiedniej narracji i przyjaznych warunków przebywania w muzeum" [Folga-Januszewska 2015: 135].

Wszystkie powyższe założenia złożyły się na punkt wyjścia do budowy zespołu projektowego „Badania publiczności muzeów w Polsce”. Cały zespół projektu liczy trzy osoby: dwoje badaczy socjologów: prof. USWPS dr. hab. Piotra Tadeusza Kwiatkowskiego, łączącego wcześniejsze doświadczenie pracy w firmach badania rynku z obecnie rozwijaną pracą naukowo-badawczą; dr Beatę Nessel-Łukasik, historyka sztuki i socjologa, pracownicę Muzeum Józefa Piłsudskiego w Sulejówku i autorkę programów badania społeczności lokalnej i publiczności muzeów; oraz koordynującą pracę zespołu pomysłodawczynię projektu Joannę Grzonkowską, kierującą Działem Strategii i Analiz Prawnych NIMOZ. Zespół korzysta ze wsparcia merytorycznego pracowników NIMOZ, niemniej jednak wszystkie opisane dalej badania przeprowadzone zostały przez dwoje wymienionych wyżej badaczy socjologów kultury.

Punktem wyjścia dla badań publiczności w kolejnych edycjach jest inny prowadzony przez NIMOZ od 2013 roku projekt pt. „Statystyka muzeów”. Powstał, by wesprzeć statutowe zadania Instytutu, takie jak gromadzenie, opracowywanie i udostępnianie danych o muzeach w Polsce. Na podstawie danych gromadzonych w projekcie "Statystyka muzeów” NIMOZ rokrocznie wydaje publikację podsumowującą funkcjonowanie muzeów w danym roku - składającą się z raportów eksperckich oraz zwizualizowanych danych statystycznych. Raporty te dostępne są na stronie internetowej www.nimoz.pl [NIMOZ 2018]. Ponadto NIMOZ opracowuje dane wykorzystywane przez sam Instytut w pracach programowych, strategicznych i legislacyjnych, zarówno własnych, jak i prowadzonych na zlecenie Ministerstwa Kultury i Dziedzictwa Narodowego, a także opracowuje raporty 
dla zainteresowanych naukowców, uczelni, organizatorów muzeów, stowarzyszeń i środowisk muzealniczych. Dane te wykorzystujemy również podczas współpracy na specjalistycznych forach międzynarodowych. Dane projektu „Statystyka muzeów", gromadzone poprzez ankietę podstawową dla muzeów bezoddziałowych, oddziałowych i dla oddziałów oraz uzupełniające ankiety tematyczne pozwalają wzbogacić dane uzyskiwane z GUS, o informacje dotyczące specjalistycznej działalności muzealnej będącej poza zainteresowaniem GUS.

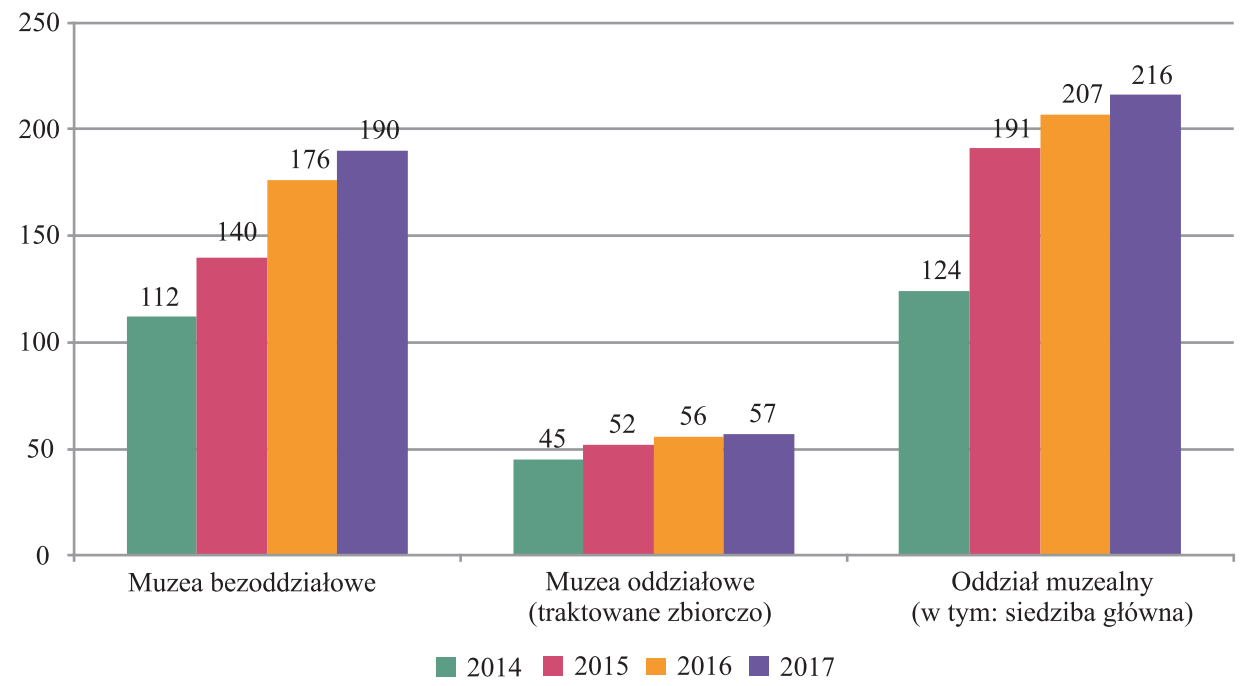

Wykres 2. Liczba muzeów biorących udział w projekcie NIMOZ „Statystyka muzeów” z podziałem na rodzaj instytucji

Źródło: opracowanie własne na podstawie danych NIMOZ.

W wypadku wszystkich trzech odsłon projektu „Badania publiczności” ankiety internetowe rozsyłane były do tych muzeów, które od 2014 roku w ankiecie projektu „Statystyka muzeów” zaznaczyły odpowiedź pozytywną na pytanie o prowadzenie badań publiczności. Dane te zestawiamy z pozostałymi informacjami z projektu „Statystyka muzeów”. Istotne jest, że projekt „Statystyka muzeów” zbiera dane od muzeów w rozumieniu ustawy z dnia 21 listopada 1997 roku o muzeach, a także tych, które statutu ani regulaminu z Ministrem Kultury i Dziedzictwa Narodowego nie uzgodniły, choć uważają, że ich działalność jest działalnością muzealną i chcą, co istotne, ankietę statystyczną NIMOZ wypełnić. Projekt „Statystyka muzeów” jest bowiem projektem dobrowolnym, do udziału w którym NIMOZ muzea wyłącznie zachęca. 


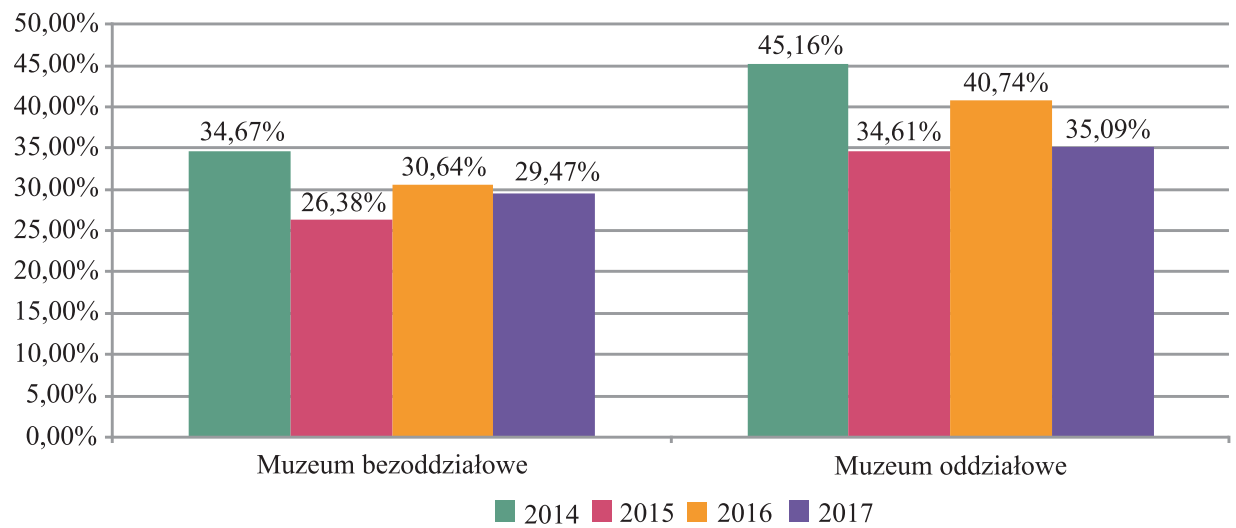

Wykres 3. Badania wizerunkowe oraz struktura publiczności w muzeach biorących udział w projekcie NIMOZ „Statystyka muzeów” z podziałem na rodzaj instytucji

Źródło: opracowanie własne na podstawie danych NIMOZ.

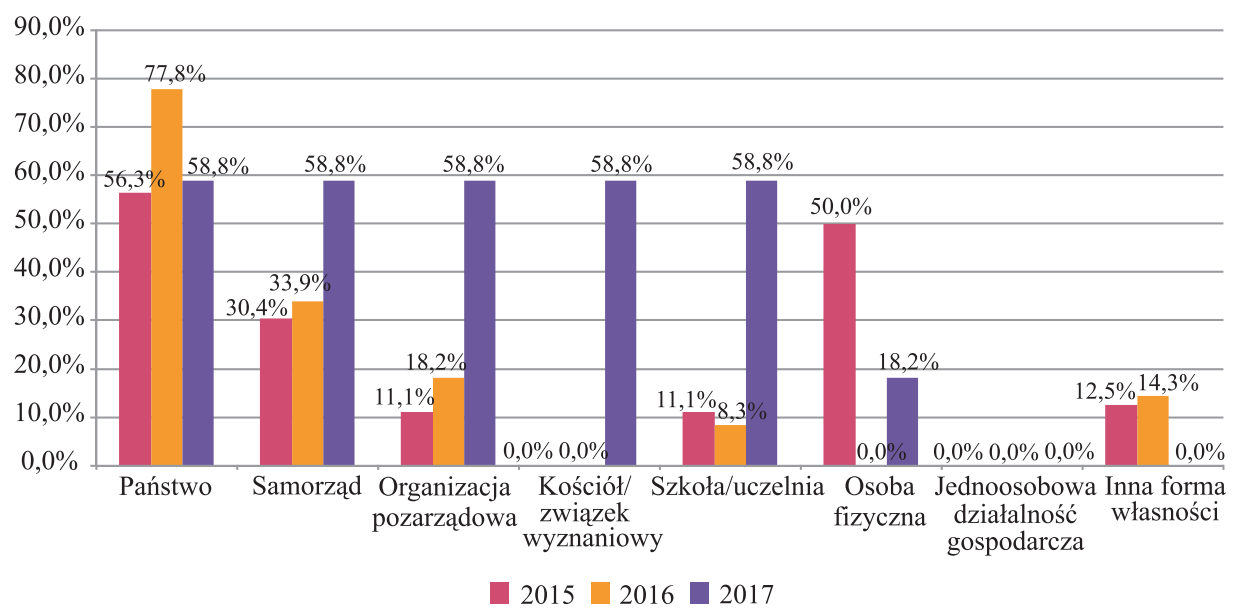

Wykres 4. Badania wizerunkowe oraz struktura publiczności w muzeach biorących udział w projekcie NIMOZ „Statystyka muzeów” z podziałem na organizatorów muzeów

Źródło: dane NIMOZ.

Pilotaż projektu „Badania publiczności” zainicjowany został w marcu 2017 roku. Jako główne cele pilotażu zespół przyjął: (1) określenie stanu badań prowadzonych przez muzea w Polsce wśród odwiedzających je osób, (2) opracowanie rekomendacji dotyczących rozwoju badań w kolejnych latach, (3) przegląd literatury naukowej oraz dostępnych badań. Prace rozpoczęliśmy od przeglądu dostępnej literatury, w tym udostępnionych przez muzea raportów z przeprowadzonych przez nie badań, a także 
przeglądu publikacji naukowych. Następnie opracowana została ankieta internetowa, o której wypełnienie poproszono przedstawicieli muzeów, które wcześniej, w trakcie realizowanego przez NIMOZ projektu „Statystyka muzeów” deklarowały prowadzenie badań swojej publiczności. Link do ankiety wysłano do 104 muzeów, odpowiedzi udzieliło 63.

Następnym etapem było przeprowadzenie wywiadu grupowego $\mathrm{z}$ wolontariuszami muzeów warszawskich oraz warsztatu z udziałem pracowników NIMOZ wyspecjalizowanych $\mathrm{w}$ pracy $\mathrm{z}$ muzeami $\mathrm{w}$ różnych dziedzinach ich działalności oraz zaproszonych do współpracy przedstawicieli bardziej doświadczonego w tego typu projektach Narodowego Centrum Kultury. W kolejnym etapie przeprowadzone zostały przez dr Beatę Nessel-Łukasik i prof. Piotra Tadeusza Kwiatkowskiego badania terenowe. Od lipca do września prowadzono badania jakościowe z zastosowaniem indywidualnych wywiadów pogłębionych (22) i dyskusji grupowych (11) w dwunastu instytucjach reprezentujących różne typy muzeów, podczas których przedstawiciele poszczególnych instytucji oraz osoby współpracujące z nimi (wolontariusze, przewodnicy i in.) określili, jak postrzegają dane muzeum i jego publiczność oraz łączące ich relacje, jak również nakreślili najważniejsze ich zdaniem kierunki badań. Celem badań, zarówno ilościowych, jak i jakościowych, było ustalenie: (1) jakimi metodami polskie muzea prowadzą badania publiczności, (2) kto w poszczególnych placówkach odpowiada za aktywność badawczą, (3) jak w strukturze instytucji funkcjonują wyniki, (4) jakie są potrzeby szkoleniowe muzeów w zakresie poznawania publiczności.

W grudniu 2017 roku na podstawie przeprowadzonych badań opracowano raport Publiczność muzeów w Polsce. Badania pilotażowe [Kwiatkowski, Nessel-Łukasik 2017]. Przeprowadzone wywiady pozwoliły pozytywnie zweryfikować wcześniejsze przekonanie zespołu, że każde muzeum ma własną publiczność, dodatkowo jeszcze zróżnicowaną wewnętrznie. Nawet muzea zlokalizowane przy tej samej ulicy mogą mieć zupełnie różnych odwiedzających, zależnie od tematu muzeum i profilu zbiorów, a także przygotowanej oferty edukacyjnej. Dowiedzieliśmy się również, że zwykle badania publiczności prowadzi się w muzeach w sposób tradycyjny, tzn. z wykorzystaniem ankiety papierowej, a celem badań jest zazwyczaj: (1) przeprowadzenie studiów zwyczajów i postaw odwiedzających dla celów segmentacji publiczności, (2) zbadanie opinii na temat aktywności muzeum, (3) poznanie wizerunku muzeum, głównie dla celów promocji i marketingu, (4) zbieranie danych statystycznych - przeważnie dla GUS, organizatora lub NIMOZ. Badania prowadzą zwykle sami pracownicy muzeów. Do rzadkości należy zatrudnianie wyspecjalizowanych firm badawczych, współpraca z uczelniami wynika zaś zazwyczaj z inicjatywy samych uczelni. Rekomendacje sformułowane przez badaczy dotyczyły opracowania i cyklicznego prowadzenia szkoleń dla pracowników muzeów dotyczących metod prowadzenia badań oraz opracowania zestawów dobrych praktyk i poradników. Obie rekomendacje zespół zrealizował w roku 2018 w NIMOZ - opracowano i przeprowadzono 
szkolenia „Badania publiczności muzealnej” (do końca maja 2019 roku odbyły się trzy jego edycje i przeszkolono około 70 osób) oraz opracowano i opublikowano książeczkę pt. $A B C$ Badania publiczności w muzeum, zawierającą materiały uzupełniające szkolenia, ale mogące służyć także osobom, które w szkoleniu nie brały udziału (ilustracja 1) [Kwiatkowski, Nessel-Łukasik 2018b].

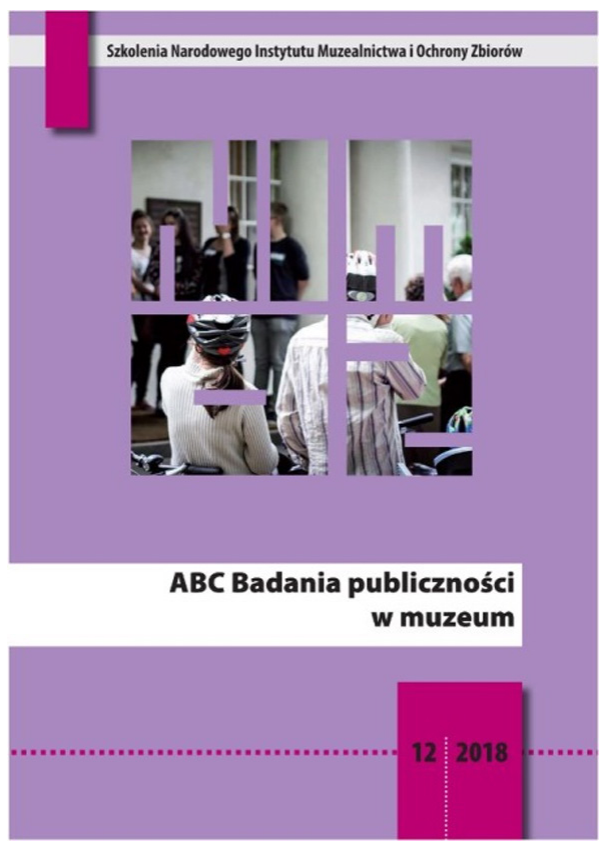

Ilustracja 1. Publikacja $A B C$ Badania publiczności w muzeum, autorstwa Piotra Tadeusza Kwiatkowskiego i Beaty Nessel-Łukasik

Źródło: Narodowy Instytut Muzealnictwa i Ochrony Zbiorów.

W 2018 roku zdecydowano się na kontynuację projektu badawczego, przy równoczesnym rozwijaniu części edukacyjnej (szkolenia, publikacja). Edycję 2018 poświęcono społecznej roli muzeów. W kwietniu 2018 przeprowadziliśmy ankietę internetową - link wysłaliśmy do 181 muzeów bezoddziałowych oraz 48 muzeów oddziałowych (w sumie do 187 oddziałów) uczestniczących w projekcie „Statystyka muzeów" i otrzymaliśmy odpowiedzi z 72 muzeów bezoddziałowych oraz $38 \mathrm{mu}$ zeów oddziałowych (w sumie z 74 oddziałów), przy czym badanie dotyczyło także jednostek niebędących muzeami w rozumieniu ustawy o muzeach. Ze względu na różne lokalizacje oddziałów muzeów oddziałowych (czasem nawet w innych województwach) zdecydowaliśmy potraktować każdy z oddziałów jako osobny podmiot z własną publicznością. W ankiecie pytaliśmy o: (1) zasięg terytorialny społecznego 
oddziaływania muzeum (oddziału), (2) relacje z władzami samorządowymi - ich ocenę, czynniki sprzyjające współpracy i bariery, (3) współpracę muzeum (oddziału) z organizacjami, instytucjami, środowiskami działającymi w społeczności lokalnej i w regionie, (4) korzyści wynikające ze współpracy muzeum (oddziału) z władzami samorządowymi i organizacjami, instytucjami, środowiskami działającymi w społeczności lokalnej i w regionie: dla muzeów oraz dla społeczności.

Pytania te stanowiły punkt wyjścia do rozmów przeprowadzonych w czasie kolejnego etapu projektu - badań terenowych, którymi objęliśmy 12 muzeów z różnych regionów Polski, różnego typu i organizatora, wybranych w czasie warsztatu z pracownikami NIMOZ. W każdym z muzeów przeprowadzone zostały rozmowy z przedstawicielami dyrekcji bądź kierownikami oraz osobami najsilniej zaangażowanymi w kontakty ze społecznym otoczeniem placówki, a także z przedstawicielami władz samorządowych oraz reprezentantami wybranych organizacji, instytucji i środowiskami współpracujących z tymi muzeami (w sumie 34 indywidualne wywiady pogłębione i 16 wywiadów grupowych).

W grudniu 2018 roku opublikowaliśmy na stronie internetowej NIMOZ dokument podsumowujący tę edycję projektu - Muzeum w społeczności lokalnej. Raport [Kwiatkowski, Nessel-Łukasik 2018a]. Podstawowa informacja wynikająca z tej edycji projektu jest taka, że - zdaniem uczestników badań - społeczność lokalna umieszczana jest w kolejności ważności dla muzeum zaraz po młodzieży/uczniach, seniorach i dzieciach. Ponieważ adresatem naszych działań są przede wszystkim pracownicy muzeów i same instytucje, rekomendacje sformułowane przez badaczy, także do muzeów i muzealników się odnoszą. Podstawą współdziałania ze społecznością lokalną musi być dobra komunikacja, otwartość, celowość działań muzeum w jego otoczeniu (społeczność musi wiedzieć, do czego muzeum zmierza, musi widzieć sens w działaniu), obecność muzeum poza samym budynkiem, wyjście do ludzi, dostrzeżenie i rozwijanie różnych wymiarów relacji (a także świadomość konsekwencji tych relacji i naszych posunięć nie tylko dla muzeum), osadzenie muzeum w pewnej sieci relacji i powiązane z tym dbanie o wzajemne (co istotne) korzyści z tej współpracy i relacji [Kwiatkowski, Nessel-Łukasik 2018a: 60]. Szczególnie właśnie w relacji z najbliższymi sąsiadami muzeum musi myśleć o odbiorcy jako o partnerze, stałym elemencie działań własnych, wspólnych i nie tylko takich, które samo inicjuje i przy których ustanawia własne warunki, ale także takich, którym ustanawia i przy których narzuca (przynajmniej częściowo) warunki publiczność.

Tegoroczna edycja projektu pt. Formy obecności osób starszych w muzeach jest jeszcze w toku. Jak zwykle, zaczęliśmy od przeglądu istniejącej literatury oraz wyników naszych badań $\mathrm{z}$ lat poprzednich, które mogłyby być przydatne $\mathrm{w}$ analizie tematu tegorocznego. Ze względu na różnorodność doświadczeń i działań poszczególnych oddziałów muzeów wielooddziałowych, podobnie, jak w roku 2018, poprosiliśmy muzea o wypełnienie ankiety internetowej dla każdego oddziału osobno. Wysłaliśmy linki do 251 muzeów - w tym: 186 bezoddziałowych i 65 oddziałowych - razem do 
450 podmiotów (muzeów państwowych, samorządowych, tzw. prywatnych wszystkich typów założycieli i do jednostek niebędących muzeami w rozumieniu ustawy o muzeach). Teraz czas na podsumowanie wyników i postawienie nowych pytań, na przykład o dzisiejsze rozumienie przez muzealników pojęcia „zwiedzający - senior”, skoro na co dzień określamy tak zarówno osoby $65+$, jak i $85+$. A to przecież dopiero początek. „W grupie seniorów wyróżnia się trzy typy zwiedzających: zwiedzający typu poznawczego, emocjonalnego i typy zwiedzających aktywnych" [Skutnik 2015: 270]. Może, skądinąd udana i popularna, koncepcja Uniwersytetu Trzeciego Wieku nie dla wszystkich zwiedzających seniorów jest najbardziej wymarzoną formą spędzania czasu w muzeum? Nasze propozycje odpowiedzi - wynikające z tegorocznych badań - przedstawimy w raporcie pod koniec roku 2019.

Podsumowując efekty pracy zespołu z ostatnich dwóch i pół roku, możemy wymienić wśród wniosków i zdobytej wiedzy kilka potwierdzonych wynikami badań wcześniejszych założeń, ale i kilka zaskoczeń. Potwierdziliśmy przypuszczenie, że każde muzeum ma własną publiczność, dodatkowo wewnętrznie zróżnicowaną, trudno więc będzie o recepty uniwersalne. Zdobyliśmy świadomość, że pracownicy muzeów w większości starają się prowadzić badania samodzielnie i że potrzebują do tego wsparcia merytorycznego i zaplecza szkoleniowego, a konstatację tę staramy się przekuć w czyny, organizując szkolenia i publikując poradniki. Zdobyliśmy świadomość, że wciąż nie wszystkie muzea rozumieją, po co prowadzi się badania publiczności, i nawet prowadząc je, nie do końca potrafią ich wyniki wykorzystać z pożytkiem dla publiczności, ale przede wszystkim dla samego muzeum. W końcu zdobyliśmy też świadomość, że i my musimy badać po kolei poszczególne grupy publiczności, i powinniśmy nauczyć tego także muzea - poznawania etapami kolejnych grup.

Założenie, jakie przyjęliśmy w pilotażu - wybranie niewielkiej stosunkowo, ale reprezentatywnej do muzeów polskich grupy instytucji - okazało się słuszne organizacyjnie. Dla wąskiego zespołu (dwoje badaczy wspieranych przez piszącą te słowa koordynatorkę projektu) było to jedyne możliwe rozwiązanie. Przyniosło nam jednak wiedzę o poszczególnych przebadanych zagadnieniach. Tym doświadczeniem i wnioskiem chcielibyśmy podzielić się z muzeami: jeśli nie możemy zlecić wyspecjalizowanej instytucji przeprowadzenia szeroko zakrojonych badań w muzeum i wokół niego (co, oczywiście, byłoby najlepszym wyjściem), możemy nie zrobić nic albo zacząć badania na małą skalę i prowadzić je własnymi siłami. Na pewno w tym drugim przypadku efekty będą lepsze niż w pierwszym. A kiedy już będzie nas stać na zatrudnienie profesjonalistów, będziemy rozumieli, o czym do nas mówią i jak możemy wykorzystać wyniki ich pracy.

Po dwóch i pół roku trwania projektu i po pięciu latach zadawania muzeom w ankietach "Statystyki muzeów” pytania o prowadzenie badań publiczności, możemy powiedzieć $\mathrm{z}$ całą pewnością, że badania prowadzi coraz więcej instytucji. I może ta pozytywna moda stanie się w przyszłości w pełni potrzebą samych instytucji i ich 
pracowników. Może wyniki badań będą analizowane pod kątem informacji przydatnych dla zarządzania instytucją, jej zbiorami, kreowania oferty dla publiczności różnych typów, a może nawet świadomego określania najważniejszej dla konkretnej instytucji grupy odbiorców, przy równoczesnym zachowaniu dbałości o wszystkich możliwych zwiedzających. Z tą właśnie nadzieją wnioskami z wszystkich naszych badań oraz materiałami szkoleniowymi dzielimy się z muzeami i wszystkimi innymi zainteresowanymi za pośrednictwem zakładki „Publiczność muzeów” na stronie internetowej NIMOZ [www.nimoz.pl/dzialalnosc/projekty/publicznosc-muzeow] i z satysfakcją obserwujemy rosnące zainteresowanie badaniami publiczności instytucji kultury w Polsce.

\section{Bibliografia}

Folga-Januszewska D. (2015), Muzeum: fenomeny i problemy, Kraków: Universitas.

Grzonkowska J. (2019), Status muzeów prywatnych w świetle obowiązującej ustawy o muzeach, [w:] N. Błażejczyk, P. Majewski (red.), Muzea kościelne wobec nowych wyzwań, Warszawa: Narodowy Instytut Muzealnictwa i Ochrony Zbiorów, s. 147-156.

GUS (2018a), Kultura w 2017 r., https://stat.gov.pl/obszary-tematyczne/kultura-turystyka-sport/ kultura/kultura-w-2017-roku,2,15.html\# [odczyt: 30.05.2019].

GUS (2018b), Turystyka w $2018 \mathrm{r}$., https://stat.gov.pl/obszary-tematyczne/kultura-turystyka-sport/turystyka/turystyka-w-2017-roku,1,15.html\# [odczyt: 30.05.2019].

GUS (2018c), Ludność. Stan i struktura oraz ruch naturalny w przekroju terytorialnym $w 2017$ r.

Stan $w$ dniu 31 XII, https://stat.gov.pl/obszary-tematyczne/ludnosc/ludnosc/ludnosc-stan-i-struktura-oraz-ruch-naturalny-w-przekroju-terytorialnym-w-2017-r-stan-w-dniu-31-xii,6,23.html\# [odczyt: 30.05.2019].

Kwiatkowski P.T., Nessel-Łukasik B. (2017), Publiczność muzeów w Polsce. Badania pilotażowe. Raport, https://nimoz.pl/files/articles/187/Raport\%20Publiczno\%C5\%9B\%C4\%87\%20 muze\%C3\%B3w\%20w\%20Polsce\%202017.pdf [odczyt: 26.05.2019].

Kwiatkowski P.T., Nessel-Łukasik B. (2018a), Muzeum w społeczności lokalnej. Raport, https:// nimoz.pl/files/articles/212/Raport\%20Publiczno\%C5\%9B\%C4\%87\%20muze\%C3\%B3w $\% 20$ w\%20Polsce\%202018.pdf [odczyt: 26.05.2019].

Kwiatkowski P.T., Nessel-Łukasik B. (2018b), ABC Badania publiczności w muzeum, Warszawa: Narodowy Instytut Muzealnictwa i Ochrony Zbiorów.

NIMOZ (2018), Muzea w 2017 r. Statystyka muzeów, z. 2.

Skutnik J. (2015), Krzesło w muzeum - o obecności seniorów w muzeum, „Dyskursy Młodych Andragogów", t. 18, s. 266-278.

Ustawa z dnia 21 listopada 1997 r. o muzeach, Dz.U. 1997 nr 5 poz. 24 ze zm. 
